\title{
Deciphering the pig genome to understand gamete production
}

\author{
G.A. Rohrer, T.H, Wise and J.J. Ford
}

USDA, ARS, U.S. Meat Animal Research Center, Spur 18, PO Box 166, Clay Center, NE 68933-0166

The field of livestock genomics has made considerable advances in the past decade. In the area of pig reproduction, a number of genome scans have identified several genomic regions associated with variation in reproductive measures ranging from ovulation rate, litter size and testis size. Additionally, several candidate genes have been associated with variation in litter size. These studies primarily focused on developing genetic markers to facilitate selection decisions. To date, their results have made minor contributions to commercial pig performance and our knowledge on the inheritance of complex phenotypes. With the availability of additional resources for pig, as well as from human and mouse studies, future studies should be directed to identifying genetic variation that affects biological processes. To reach this goal, teams of diversely trained scientists need to be formed that include geneticists, physiologists, molecular biologists and bioinformaticists. A diversified team of scientists equipped with all of the available research tools (genomic sequence data, expression arrays, knowledge of gene product functions, etc.) and appropriate swine populations should be able to decode the genome's hidden secrets on how it controls reproductive processes.

\section{Introduction}

The field of swine genomics is now over a decade old, and in many ways, it seems that the promises this technology were projected to hold for pig production were not fulfilled. Genomic maps were likened to a "Rosetta Stone" of life holding all of the key information necessary to easily modify the performance of a species. However, the amount of information contained in a genome has proven to be immensely larger than expected and more difficult to decipher than originally thought. As a result, we are still many years away from determining an animal's productivity solely based on its genotypic profile.

The field of swine genomics is rapidly evolving as "high-throughput" technologies are de veloped and a plethora of sequence and expression data accumulates. Now that the complete sequence of the human and mouse genomes are known, many sequencing projects of other species are underway (including chicken, dog and cattle) and a proposal to collect this information for the pig has been developed. New projections on the impact this information will have on pig production are under way. Certainly not all of these projections will come to fruition, but definite advances will be made and our knowledge on how the genome affects biological processes will be greatly increased. 
The focus of this review will be to evaluate the current level of knowledge on genomics of gamete production in the pig, and then, to project the approaches that will be taken in the future. Future approaches should be team based, expound upon the current knowledge base, increase our understanding of the genome and biological processes, and result in improved reproduction rates in commercial pigs.

\section{Current status of genetic markers for reproduction}

Considerable advances in pig genomics have been made, and there are a large number of examples where this information has been used to determine breeding decisions. Most notable is the removal of the deleterious "stress gene" (Fujii et al., 1991) from pigs, but other examples include selection for reproduction (Rothschild et al., 1996), pork quality (Milan et al., 2000), growth rate (Van Laere et al., 2003) and even coat color (Kijas et al., 1998). Furthermore, most commercial breeding companies are using proprietary genetic markers to assist in breeding decisions (Lohuis, 2003; Plastow et al., 2003; Schneider et al., 2003).

Genomic studies for reproduction are quite expensive, primarily due to the number of animals that need to be measured (approximately 500 animals preferred), expense of collecting phenotypic data, and cost to collect genotypic data on all animals for 120-200 genetic markers. Therefore, not many studies have taken a genomic approach. An approach that requires fewer resources and can use commercial populations is to evaluate associations between polymorphisms in candidate genes and performance. These studies only evaluate a small portion of the genome, but if utilizing commercial populations, may include 1,000 or more animals. Bidanel et al. (2002) reviewed genetic markers in pigs and most of the information presented in this section was summarized in their publication.

\section{Results from genome scans}

To date, only six populations with reproductive measures have been thoroughly studied and reported across the globe. Five of these populations utilized Meishan germplasm as one of the founding breeds. Female reproductive traits were studied in five populations and male reproduction traits were studied in three. Results from the INRA Meishan-Large White population have only been reported in an abstract (Bidanel et al., 2001) and popular press (Bidanel et al., 2002), therefore, many of the details of this study are unavailable.

From five studies on female productive traits (Bidanel et al, 2001; Cassady et al., 2001; de Koning et al., 2001; Rohrer et al., 1999 and Wilkie et al., 1999), 24 associations, i.e. quantitative trait loci (QTL), reached the suggestive level of genome-wide significance. The only overlap was a QTL affecting age at first oestrus at the telomere of the long arm of chromosome 1 (Bidanel et al., 2001; Rohrer et al., 1999). Other findings included seven QTL for ovulation rate on chromosomes 3, 4, 7, 8 (two unique locations), 9 and 10; five QTL for age at first oestrus on chromosomes 7, 8, 10,12 and 13; five QTL for litter size on chromosomes 7, 11, 12, 14 and 17; and a QTL for uterine capacity on chromosome 8.

The QTL detected are dependent upon the founding breeds or lines used for the project. Since most studies utilized Meishan versus occidental breeds, and the Meishan has very unique reproductive characteristics, more overlap between studies would be expected. However, the studies that used Meishan germplasm and measured litter size or uterine capacity had fewer than 250 observations (de Koning et al., 2001; Rohrer et al., 1999; Wilkie et al., 1999), thus, their results may not be robust. Researchers typically attempt to have a minimum of 500 phenotyped animals for QTL studies. The only experiment that exceeded 500 records for ovulation rate or age at puberty was that of Rohrer et al. (1999). 
An unexpected similarity across studies was a preponderance of QTL where Meishan QTL alleles decreased ovulation rate. This was evident in all three journal articles that included Meishan germplasm (de Koning et al., 2001; Rohrer et al., 1999; Wilkie et al., 1999). One possible explanation is that Chinese pigs evolved with a unique set of genes regulating ovulation rate. Together as a whole, they result in a superior number of ova shed per oestrus, but the effect of an individual gene when placed in an occidental germplasm has negative epistatic effects resulting in fewer ova shed. If this is the case, it is a strong justification for studying the entire biological process involved in ova recruitment and ovulation rather than just the impact of a single genomic region to accurately understand the mechanisms behind these QTL.

The only occidental population studied compared a cross between animals from a selected line for increased ovulation rate and litter size with animals from the control line of the same experiment (Rathje et al., 1997). These lines were originally developed from a Large White by Landrace cross. The initial results from the first third of the population were reported by Rathje et al. (1997) and the results from the complete project were presented by Cassady et al. (2001). All of the QTL associations detected by Rathje et al. (1997) were not supported in the full data set (Cassady et al., 2001), indicating the need for large populations for QTL detection studies.

Genome-wide QTL studies for male reproduction traits are limited to three Meishan cross populations and only a few traits studied. Bidanel et al. (2001) indicated that they found QTL on chromosomes 4 and 7 for male sexual development traits (as referenced by Bidanel et al., 2002). The only traits reported by Sato et al. (2003) were testis weights and they identified QTL on chromosomes 3 and X. Rohrer et al. (2001) scanned the genome for QTL affecting serum $\mathrm{FSH}$ concentration in boars. Four QTL were detected on chromosomes 3, 8, 10 and X. They then tested these four regions for associations with testes weight and identified a significant association with the $X$ chromosome (Rohrer et al., 2001).

The only common finding for male reproduction QTL is the testes weight QTL on the $X$ chromosome (Rohrer et al., 2001; Sato et al., 2003). In a subsequent generation of the population studied by Rohrer et al. (2001), Ford et al. (2001) confirmed the effects of the X chromosome on serum FSH concentration and testes size, as well as determined that this region affected pubertal serum LH serum concentration and color of the parenchymal tissue of the testes. The authors currently believe that the effect on parenchymal color of the testes is a result of higher ferritin in the Leydig cells caused by elevated FSH and FSH inducement of iron transport (Wise et al., 2003). Recently, Nonneman et al. (2005) reported a polymorphism in the thyroxine binding globulin (TBG) gene that affects binding of thyroxine to the TBG molecule and showed it was significantly associated with mature testes weight. They provided circumstantial evidence that thyroxine controls the length of the proliferative phase of Sertoli cells in developing testes, resulting in a difference in mature testes size. In addition, rats that were transiently hypothyroid during this critical phase of development had significantly larger mature testes and decreased levels of serum FSH and LH (Kirby et al., 1992; 1997). Further research is necessary to definitively prove that this polymorphism actually causes the observed effect on mature testes size.

\section{Candidate gene associations}

In total, only six candidate genes have been associated with reproduction traits in pigs. Five studies evaluated litter size and the sixth study analyzed ovulation rate. Typically, these studies involved a larger sample of phenotyped animals than genome scans and often animals tested were from commercial populations. Associations of oestrogen receptor alpha (ER $\alpha$ ) and prolactin receptor (PRLR) were most thoroughly evaluated.

The association of $\mathrm{ER} \alpha$ genotypes with litter size was first reported by Rothschild et al. 
(1996) and later confirmed by Short et al. (1997a). Follow-up studies in other laboratories resulted in inconsistent results indicating that either the polymorphism genotyped is not causative or that considerable epistatic interactions exist with this locus and other gene(s) located elsewhere in the genome. However, this marker did not affect components of litter size in two independent resource populations (Bidanel et al., 2001; Rohrer et al., 1999) comparable to the first population studied by Rothschild et al. (1996), and the effects were opposite in a comparable population studied by van Rens et al. (2002a). Additionally, three studies were unable to detect a significant association of $\mathrm{ER} \alpha$ genotype with litter size (Drogemuller et al., 2001; Isler et al., 2002; Linville et al., 2001) or ovulation rate (Isler et al., 2002; Linville et al., 2001). van Rens et al. (2002b) did identify a significant interaction between $E R \alpha$ genotype of the sow and $E R \alpha$ genotype of the fetus on placental efficiency which may affect foetal survival.

The PRLR polymorphism has been studied in multiple populations. Vincent et al. (1998) identified a significant association between PRLR genotype and litter size in five commercial lines of pigs. Linville et al. (2001) was unable to detect a significant effect of this gene on litter size or ovulation rate, but Drogemuller et al. (2001) and van Rens et al. (2002c) did detect significant effects on reproduction traits. Drogemuller et al. (2001) found the $B$ allele was associated with larger litters over all parities studied in German commercial pigs. To the contrary, the A allele of PRLR was associated with larger litters, greater placental efficiency, later age at puberty (van Rens et al 2002c) and increased ovulation rate (van Rens et al., 2003) in a Meishan cross population.

A polymorphism in retinol binding protein 4 was associated with litter size by Rothschild et al. (2000). However, this finding was not confirmed by Linville et al. (2000). Only one study each demonstrated associations between litter size and genotypes for the genes FSH $ß$ subunit (Li et al., 1998), secreted phosphoprotein 1 (Short et al., 1997b) and GnRH receptor (Jiang et al., 2001).

\section{Lessons from the past}

Most candidate gene studies were designed to develop markers that could be used for breeding decisions. Typically, traits that are lowly heritable, only observed in one sex or expressed late in life were targeted since these traits are the least amenable to traditional selection procedures. Therefore, geneticists saw a need for genetic markers to improve selection for reproductive traits.

The steps necessary to reach the final objective included animal performance data, marker development, genotyping and statistical analysis. So, when "genetic" markers became available, animal breeders/geneticists began to look for associations. The first marker-phenotype association studies used blood types or serum protein polymorphisms. Jensen et al. (1968) detected an association with the $\mathrm{H}$ blood group and litter size in Hampshire and Duroc pigs. The $H$ blood group was later used in selection decisions to remove the "stress gene allele" because close linkage with the causative gene was detected (Rasmusen et al., 1976). Advancements in DNA technologies made it easier to choose a gene of interest, identify a DNA based polymorphism and genotype a population of animals. Therefore, this research was conducted by scientists trained in DNA technologies and statistical analyses without including expertise from scientists in other disciplines.

Once linkage maps, which spanned the genome, were reported (Rohrer et al., 1994; Ellegren et al., 1994; Archibald et al., 1995), genome scans for QTL could be conducted. Due to the investment necessary to complete genome scans, the phenotypes collected were more comprehensive. The design of these resource populations included input from scientists in other 
disciplines to ensure useful phenotypes were collected. Some of these resource populations have been the cornerstones of large research programs. However, all of these studies would have greatly benefited from current high-throughput "phenotyping" technologies and a greater understanding of how the genome affects performance.

\section{What is next for genomic studies of reproduction?}

The initial goal of livestock genomics (i.e., to develop genetic markers for selection) was shortsighted. An overwhelming amount of resources have gone into QTL detection in humans and mice for reasons other than marker assisted selection. These studies were conducted to understand how the genome affects biological processes. While increasing the accuracy of selection with DNA based markers will improve livestock production, a broader focus of these studies to understand biological processes is a much more valuable resource. To obtain this knowledge requires multi-disciplinary teams of scientists. Necessary team members include scientists trained in DNA technologies, physiology, molecular biology, statistical analyses and bioinformatics. Each team member is critical and it is crucial that they interact as a team. Team members need to take the lead in areas of their expertise and play a subordinate role where other members have more training. Continuous interaction between team members is also critical to successfully identify genetic variation that affects performance.

Successful examples of this approach in reproduction were demonstrated by the discovery of the causative mutations for two major genes affecting reproduction in sheep, the Booroola and Inverdale loci. Both variants were detected in the same laboratory by taking a multi-disciplinary approach (Galloway et al., 2000; Wilson et al., 2001). Simultaneous with Wilson et al. (2001), another laboratory also identified the same Booroola mutation using a similar approach (Mulsant et al., 2001).

At the U.S. Meat Animal Research Center, a multi-disciplinary approach is often taken to QTL discovery and fine-mapping. When a QTL is discovered, one of the first questions asked is "What other traits are possibly affected by the same QTL?" There are times when the answer to this question can be misleading, but it usually results in greater insight into the biology behind the QTL. One example is the work leading to the discovery of a polymorphism in TBG that was referred to earlier and is presented in greater detail in Ford et al., (2005). Briefly, a QTL for fat deposition was initially identified (Rohrer et al., 1998). As research into reproductive traits began, a QTL for serum FSH concentration in pubertal boars (Rohrer et al., 2001) was detected with a major gene effect, followed by discovery of its effect on testes weight, serum $\mathrm{LH}$ concentrations, testes color and response to unilateral castration (Ford et al., 2001). Eventually a hypothesis that thyroid function was possibly involved, led to the study of TBG (Nonneman et al., 2005). Prior to having the biology of this QTL clearly defined, research had been directed at other "candidate" genes in the area, primarily androgen receptor.

A similar integrative approach was also taken to study other traits. Each putative QTL for ovulation rate (chromosomes 3, 8 and 10; Rohrer et al., 1999) overlaps a QTL affecting serum FSH concentrations in boars (Rohrer et al., 2001). Unfortunately, differences in serum FSH concentration in females were not associated with these genomic regions at either a constant age or a constant day of the oestrous cycle (Ford et al. unpublished data). These results suggest mechanisms behind these ovulation rate QTL are related to $\mathrm{FSH}$ physiology (synthesis, catabolism, feedback, etc.) that is detectable in males, but is possibly suppressed or not detectable with current techniques in females. Additional research indicated that chromosome 10 and possibly chromosome 3 QTL are partially responsible for the increased ovulation rate measured in an 11 generation ovulation rate selected line of pigs (Mousel et al., 2004, 2005). This 
selection line is composed of Large White, Landrace, Chester White and Yorkshire germplasm, indicating that the detected QTL are not exclusively a result of a unique Meishan allele, and they will be applicable to commercial lines.

Future studies will be fortified by the wealth of genomic information available. Data of genomic sequence and function are rapidly accumulating. Comparing the genome sequence of a wide array of organisms, as demonstrated by Thomas et al. (2003), facilitates discovery of new genes, regulatory elements and untranslated transcribed RNA molecules. These novel DNA features can be studied today on a genomic level by comparing the human and mouse genome sequence. Soon, these comparisons will be enriched by the inclusion of additional species (cow, chicken, dog, etc.), and once the pig genome is sequenced, these comparisons will be directly applied to the pig.

Information on expression and function of protein coding regions (genes) will fortify genome sequence information. A plethora of data for tissue specific gene expression and protein function in man and mouse continues to expand at an extraordinary rate, and much of this information can be directly applied to the pig. A multitude of human and mouse tissue specific cDNA libraries have been developed and sequenced, resulting in millions of expressed sequence tags (EST) for each species and a well documented set of genes expressed in each tissue. A large number of EST are available for the pig and are being used to determine tissue expression profiles. Gene expression arrays also provide useful insight into metabolic pathways involved in animals with different levels of performance (Caetano et al., 2004). Finally, in the mouse, systematic modification of specific genes provided in vivo evidence of protein function of novel genes. These modifications initially utilized random mutagenesis (Wells et al., 2000; Soewarto et al., 2000) or targeted transgenic knock-outs of genes (Mills et al., 2001). But a more recent technology, which can be applied in a wider variety of species is RNA interference (Fire et al., 1998). While RNA interference could be applied in pigs, the cost to evaluate $30,000+$ genes limits this holistic approach to small model organisms like the mouse. Most likely, follow up studies on the "most interesting" genes will be conducted in pigs.

There are some limitations to comparative genomics and it is necessary that information is collected in the pig. For example, the androgen receptor gene in primates and rodents has three trinucleotide repeats in the coding region that are polymorphic, and some alleles can have significant impact on the gene's function. But these three repeats were virtually undetectable in the pig, and no genetic variation exists in commercial lines (Trakooljul et al., 2004; Ford et al., unpublished data). Therefore, a coincidental occurrence between the human and mouse genome does not always imply a universal mammalian genomic effect. This is why the Cooperative State Research, Education and Extension Service of the U.S. Department of Agriculture (USDA-CREES) decided to partially fund a genome sequencing effort for the pig.

Unfortunately, building multi-disciplinary teams to work on each QTL requires considerable resources and restricts the number of QTL that can be simultaneously studied. However, the results may have multiple applications in the species studied (pharmaceutical, nutriceutical, management, as well as marker assisted selection), can often be applied to other species and lead to a more knowledgeable application of the information. Therefore, future research needs to involve teams of scientists with a variety of expertise so that the endpoint of the research will be "How does this region of the genome affect performance?" With this knowledge in hand an "optimal" method to utilize this knowledge can be formulated that will foresee problems with pleiotropic or epistatic effects of a locus or required changes in management to capture the value of the knowledge created. 


\section{References}

Archibald AL, Haley CS, Brown IF, Couperwhite S, McQueen HA, Nicholson D, Coppieters W, Van de Weghe A, Stratil A, Wintero AK, Fredholm M, Larsen N), Nielsen VH, Milan D, Woloszyn N, Robic A, Dalens M, Riquet J, Gellin J, Caritex J-C, Burgaud C, Ollivier L, Bidanel J-P, Vaiman $M$, Renard $C$, Geldermann H, Davoli R, Ruyter D, Verstege EJM, Groenen MAM, Davies W, Heyheim B, Keiserud A, Andersson L, Ellegren $H$, Johansson $M$, Marklund $L$, Miller JR, Anderson Dear DV, Signer E, Jeffreys AJ, Moran C, Le Tissier P, Muladno, Rothschild MF, Tuggle CK, Vaske D, Helm J, Liu H-C, Rahman A, Yu T-P, Larson RG and Schmitz CB (1995) The PiGMaP consortium linkage map of the pig (Sus scrofa). Mammalian Genome 6 157-175

Bidanel JP and Rothschild $M$ (2002) Current status of quantitative trait locus mapping in pigs. Pig News and information $2339 \mathrm{~N}-53 \mathrm{~N}$

Bidanel JP, Prunier A, lannuccelli N and Milan D (2001) Detection of quantitative trait loci for male and female reproductive traits in Meishan $x$ Large White F2 pigs Proceedings of the 51 st Annual Meeting of the European Association for Animal Production 754

Caetano AR, Johnson RK, Ford /J and Pomp D (2004) Microarray profiling for differential gene expression in ovaries and ovarian follicles of pigs selected for increased ovulation rate Cenetics 168 1529-1537

Cassady JP, Johnson RK, Pomp D, Rohrer GA, Van Vleck LD, Spiegel EK and Gilson KM (2001) Identification of quantitative trait loci affecting reproduction in pigs Journal of Animal Science 79 623-633

de Koning D), Rattink AP, Harlizius B, Groenen MAM, Brascamp EW and van Arendonk JAM (2001) Detection and characterization of quantitative trait loci for growth and reproduction traits in pigs Livestock Production Science 72 185-198

Drogemuller C, Hamann $\mathbf{H}$ and Distl $\mathbf{O}$ (2001) Candidate gene markers for litter size in different German pig lines Journal of Animal Science 75 2565-2570

Ellegren $\mathrm{H}$, Chowdhary BP, Johansson M, Marklund $\mathrm{L}$, Fredholm M, Gustavsson I and Andersson L (1994) A primary linkage map of the porcine genome reveals a low rate of genetic recombination Cenetics 137 1089-1100

Fire A, Xu S, Montgomery MK, Kostas SA, Driver SE and Mello CC (1998) Potent and specific genetic interference by double-stranded RNA in Caenorhabditis elegans Nature 391 806-811

Ford IJ, Wise TH, Lunstra DD and Rohrer GA (2001) Interrelationships of porcine $X$ and $Y$ chromosomes with pituitary gonadotropins and testicular size Biology of Reproduction 65 906-912

Ford IJ, McCoard SA, Wise TH, Lunstra DD and Rohrer GA (2005) Genetic variation in sperm production In: Control of Reproduction VII pp 99-112

Fujii J, Otsu K, Zorzato F, de Leon S, Khanna VK, Weiler JE, O'Brien PJ and MacLennan DH (1991) Identification of a mutation in porcine ryanodine receptor associated with malignant hyperthermia Science $\mathbf{2 5 3}$ 448-451

Galloway SM, McNatty KP, Cambridge LM, Laitinen MPE, Juengel JL, Jokiranta TS, McLaren RJ, Luiro K, Dodds KG, Montgomery GW, Beattie AE, Davis $\mathbf{G H}$ and Ritvos $O$ (2000) Mutations in an oocyte-derived growth factor gene (BMP15) cause increased ovulation rate and infertility in a dosage-sensitive manner Nature Cenetics 25 279-283

Isler BJ, Irvin KM, Neal SM, Moeller SI and Davis ME (2002) Examination of the relationship between the estrogen receptor and reproductive traits in swine Journal of Animal Science 80 2334-2339

Jensen EL, Smith C, Baker LN and Cox DF (1968) Quantitative studies on blood group and serum protein systems in pigs. II. Effects on production and reproduction Journal of Animal Science 27 856-862

jiang Z, Gibson JP, Archibald AL and Haley CS (2001) The porcine gonadotropin-releasing hormone receptor gene (GNRHR): genomic organization, polymorphisms, and association with the number of corpora lutea Genome 44 7-12

Kijas IM, Wales R, Tornsten A, Chardon P, Moller $M$ and Andersson L (1998) Melanocortin receptor 1 (MC1R) mutations and coat color in pigs Cenetics 1501177. 1185

Kirby JD, Jetton AE, Cooke PS, Hess RA, Bunick D, Ackland JF, Turek FW and Schwartz NB (1992) Developmental hormonal profiles accompanying the neonatal hypothyroidism-induced increased in adult testicular size and sperm production in the rat Endocrinology $131559-565$

Kirby JD, Arambepola N, Porkka-Heiskanen T, Kirby YK, Rhoads ML, Nitta H, Jetton AE, Iwamotto G, Jackson Gl., Turek FW and Cooke PS (1997) Neonatal hypothyroidism permenantly alters follicle-stimulating hormone and luteininzing hormone production in the male rat Endocrinology 138 2713-2721

Li N, Zhao YJ, Xiao L, Zhang FJ, Chen YZ, Dai RJ, Zhang IS, Shen SQ, Chen YF, Wu CX (1998) Candidate gene approach for identification of genetic loci controlling litter size in swine Proceedings of the 6th World Congress on Cenetics Applied to Livestock Production 26 183-186

Linville RC, Pomp D, Johnson RK, Rothschild MF (2001) Candidate gene analysis for loci affecting litter size and ovulation rate in swine fournal of Animal Science 79 60-67

Lohuis MM (2003) Industry use of marker-assisted selection Proceedings of the 28th Annual National Swine Improvement Federation pp 170-174

Milan D, Jeon JT, Looft C, Amarger V, Robis A, Thelander M, Rogel-Gaillard C, Paul S, lannuccelli N, Rask L, Ronne H, Lundstrom K, Reinsch N, Gellin J, Kalm E, LeRoy P, Chardon P and Andersson L (2000) A mutation in PRKAG3 associated with excess glycogen content in pig skeletal muscle Science 288 12481251 
Mills AA and Bradley A (2001) From mouse to man: generating megabase chromosome rearrangements Trends in Cenetics 17 331-339

Mousel MR, Rohrer GA, Leymaster KA and Christenson RK (2004) Validation of QTL's in a swine population selected for ovulation rate Journal of Animal Science (Supplement 1) 82452

Mousel MR, Rohrer GA, Leymaster KA and Christenson RK (2005) Fine mapping of a QTL in a swine population selected for ovulation rate Journal of Animal Science (Supplement 1) 83 231-232

Mulsant P, Lecerf F, Fabre S, Schibler L, Monget P, Lanneluc I, Pisselet C, Riquet J, Monniaux D, Callebaut I, Cribiu E, Thimonier J, Teyssier J, Bodin L, Cognie Y, Chitour N and Elsen IM (2001) Mutation in the bone morphogenetic protein receptor-IB is associated with increased ovulation rate in Booroola Merino ewes Proceedings of the National Academy of Science 98 5104-5109

Nonneman D, Rohrer GA, Wise TH, Lunstra DD and Ford I/ (2005) A variant of porcine thyroxine-binding globulin has reduced affinity for thyroxine and is associated with testis size Biology of Reproduction 72 214-220

Plastow G, Sasaki S, Yu TP, Deeb N, Prall G, Siggens K and Wilson E (2003) Practical applications of DNA markers for genetic improvement Proceedings of the $28^{\text {th }}$ Annual National Swine Improvement Federation pp 150-154

Rasmusen BA and Christian LL. (1976) H blood types in pigs as predictors of stress susceptibility Science $191947-948$

Rathje TA, Rohrer GA and Johnson RK (1997) Evidence for quantitative trait loci affecting ovulation rate in pigs Journal of Animal Science 75 1486-1494

Rohrer GA and Keele IW (1998) Identification of quantitative trait loci affecting carcass composition in swine: I. fat deposition traits lournal of Animal Science 76 2247-2254

Rohrer GA, Alexander LJ, Keele JW, Smith TP and Beattie CW (1994) A microsatellite linkage map of the porcine genome Cenetics 136 231-245

Rohrer GA, Ford J, Wise TH, Vallet JL and Christenson RK (1999) Identification of quantilative trait loci affecting female reproductive traits in a multigeneration Meishan-White Composite swine population fournal of Animal Science 77 1385-1391

Rohrer GA, Wise TH, Lunstra DD and Ford J (2001) Identification of genomic regions controlling plasma FSH concentrations in Meishan-White Composite boars Physiological Cenomics 6 145-151

Rothschild M, Jacobson C, Vaske D, Tuggle C, Wand L, Short T, Eckardt G, Sasaki S, Vincent A, McLaren D, Southwood O, van der Steen $H$, Mileham $A$ and Plastow G (1996) The estrogen receptor locus is associated with a major gene influencing litter size in pigs Proceedings of the National Academy of Science 93 201-205

Rothschild MF, Messer LA, Day A, Wahs R, Short T, Southwood $O$ and Plastow $G$ (2000) Investigation of the retinol binding protein (RBP4) gene as a candidate gene for litter size in the pig Mammalian Genome 11 75-77

Sato S, Oyamada Y, Atsuji K, Nade T, Sata S, Kobayashi E, Mitsuhashi T, NirasawaK, Komatsuda A, Saito $Y$, Terai S, Hayashi T and Sugimoto $Y$ (2003) Quantitative trait loci analysis for growth and carcass traits in a Meishan $X$ Duroc $F 2$ resource population lournal of Animal Science 81 2938-2949

Schneider JF and Bierman CD (2003) Use of markerassisted selection in Babcock Cenetics programs Proceedings of the 28th Annual National Swine $1 \mathrm{~m}$ provement Federation pp 164-169

Short TH, Rothschild MF, Southwood OI, McLaren DG, DeVries A, van der Steen H, Eckardt GR, Tuggle CK, Helm J, Vaske DA, Mileham AJ and Plastow GS (1997a) Effects of the estrogen receptor locus on reproduction and production traits in four commercial pig lines fournal of Animal Science 75 3138-3142

Short TH, Southwood OI, DeVries A, McLaren DG, Evans GJ, Mileham AJ and Plastow GS (1997b) Evidence of a new genetic marker for litter size in pigs Journal of Animal Science (Supplement I) 7529

Soewarto D, Fella C, Teubner A, Rathkolb B, Pargent W, Heffner S, Marschall S, Wolf, E, Balling $R$ and Hrabe de Angelis H (2000) The large-scale Munich ENU-mouse-mutagenesis screen Mammalian Cenome $11507-510$

Thomas IW, Touchman IW, Blakesley RW, Bouffard GG, Beckstrom-Sternberg SM, Margulies EH, Blanchette M, Siepel AC, Thomas PJ, McDowell JC, Maskeri B, Hansen NF, Schwartz MS, Weber R], Kent WJ, Karolchik D, Bruen TC, Bevan R, Cutler DJ, Schwartz S, ELnitski L, Idol JR, Prasad AB, LeeLin SQ, Maduro VVB, Summers TJ, Portnoy ME, Dietrich NL, Akhter N, Ayele K, Benjamin B, Cariaga K, Brinkley CP, Brooks SY, Granite S, Guan X, Gupta J, Haghighi P, Ho SL, Huang MC, Karlins E, Laric PL, Legaspi R, Lim MI, Maduro QL, Masiello CA, Mastrian SD, McCloskey IC, Pearson R, Stantripop S, Tiongson EE, Tran JT, Tsurgeon C, Vogt JL, Walker MA, Wetherby KD, Wiggins LS, Young AC, Zhang LH, Osoegawa K, Zhu B, Zhao 8, Shu CL, De Jong PJ, Lawrence CE, Smit AF, Chakravarti A, Haussler D, Green P, Miller W and Green ED (2003) Comparative analyses of multi-species sequences from targeted genomic regions Nature 424 788-793

Trakooljul N, Ponsuksili S, Schellander K, Wimmers K (2004) Polymorphism of the porcine androgen receptor gene affecting its amino acid sequence and expression level Biochimica et Biophysica Acta 1678 94-101

Van Laere AS, Nguyen M, Braunschweig M, Nezer C, Colfette C, Moreau L, Archibald A, Haley CS, Buys $N$, Tally $M$, Andersson $G$, Ceorges $M$ and Andersson L (2003) A regulatory mutation in IGF2 cause a major QTL effect on muscle growth in the pig $\mathrm{Na}$ ture 425 832-836

van Rens BTTM, de Groot PN and van der l.ende $T$ (2002a) The effect of estrogen receptor genotype on litter size and placental traits at term in $\mathrm{F} 2$ crossbred gilts Theriogenology 57 1635-1649 
van Rens BTTM and van der Lende T (2002b) Piglet and placental traits at term in relation to the estrogen receptor genotype in gilts Theriogenology 57 16511667

van Rens BTTM and van der Lende T (2002c) Litter size and piglet traits of gilts with different prolactin receptor genotypes Theriogenology 57 883-893

van Rens BTTM, Evans GJ and van der Lende T (2003) Components of litter size in gilts with different prolactin receptor genotypes Theriogenology 59 915-926

Vincent Al, Evans G, Short TH, Southwood OI, Plastow GS, Tuggle CK and Rothschild MF (1998) The prolactin receptor gene is associated with increased litter size in pigs Proceedings of the 6th World Congress on Cenetics Applied to Livestock Production pp 15-18

Wells C and Brown SDM (2000) Genomics meets genetics: towards a mutant map of the mouse Mammalian Cenome 11 472-477
Wilkie PJ, Paszek AA, Beattie CW, Alexander LJ, Wheeler MB and Schook LS (1999) A genomic scan of porcine reproductive traits reveals possible quantitative trait loci (QTL.s) for number of corpora lutea Mammalian Cenome 10 573-578

Wilson T, Wu XY, Juengel JL, Ross IK, Lumsden JM, Lord EA, Dodds KG, Walling GA, McEwan JC, O'Connell AR, McNatty KP and Montgomery GW (2001) Highly prolific Booroola sheep have a mutation in the intracellular kinase domain of the bone morphogenetic protein IB receptor (ALK-6) that is expressed in both oocytes and granulose cells Biology of Reproduction 64 1225-1235

Wise T, Lunstra DD, Rohrer GA and Ford IJ (2003) Relationships of testicular iron and ferritin concentrations with testicular weight and sperm production in boars fournal of Animal Science 81 503-511 